\title{
DESTINATIONS: EUROPEAN PATHS TO DEMOCRACY AND DECEPTIONS OF ANTI-AMERICANISM
}

\author{
Nikola Samardžić, University of Belgrade, Serbia \\ nikolasamardzic@gmail.com
}

10.31902/fll.24.2018.9

UDK 321.7:316.72

\begin{abstract}
Democracy comprises free elections and media, efficient government and civic society, prevailing private or corporate ownership, free trade and market economy, trans-border integration and cooperation. National and social utopism usually tend to relativize, or contest one of the above mentioned democratic braces. As modern democratic roots rest in former British Commonwealth and protestant states (maybe together with France), the future destination of liberal consensus still depends on interconnections between the democratic European states and the U.S. If the democratic core fails, the peripheries will surely rapidly deteriorate. Contemporary European Anti-Americanism mainly refers to inherent European issues: EU common market and capitalism, NATO and strategic defense from authoritarian or terrorist threats (Russia, China, Middle East and internal pockets of "multicultural" political Islam). Anti-Americanism is based on lies or halftruths on supposed political, financial and military global imperialism, moral disputability of capitalism, corporate greediness and debt bondage, American leadership in global pollution and climate change. Contemporary European Anti Americanism brings together political and intellectual extremism form both the left and the right challenging the concepts of individual, political and economic freedom, European concept of borders suspension and the development of individual freedom. The Russian hybrid war against the European Union is successfully using media propaganda and current social and national discontents. Challenging the Western liberal-democratic consensus, European social scientists have paved ideological paths for Russian and Chinese breakthroughs into Southeastern and Eastern Europe, etc. As AntiAmericanism is locally used, in political practices, as means of contesting European and regional integrations, deceptions in Anti-Americanism will be analyzed especially in the context of new future destinations of Montenegro directed towards Atlantic and European institutions and cooperation.
\end{abstract}

Keywords: Anti-Americanism, European Union, Russia, China, Montenegro.

The accession to NATO (2017) has opened to Montenegro a new path to a faster development and improvement of regional strategic and political structure. It is necessary to emphasize that by joining the NATO Montenegro has established new intensive ties with 
the U.S. and Britain. Montenegro is thus approaching the U.S. and British spheres of influence, primarily in the eastern Mediterranean. In global affairs, the U.S. and Britain remain the most desirable destinations for the immigrants. Their respectable political systems, institutions, values are role models of democratic dynamics and social mobility. On the other hand, the interpretations of the U.S. conduct in international relations, together with British political exclusivities and remembrances colonialism, represent the U.S. and Britain as disputable or controversial from the perspectives of backward developing states.

Montenegro has made huge steps towards democratization and admittance into the Euro-Atlantic world. However, the acceptance of liberal democracy and integration was facing local, regional and global resistance. Montenegro was leaving the communist period during decade of violent Yugoslav disintegration, and emerged again as a society deeply divided over all the important dilemmas of the past and the future: relations with Serbia and other former Yugoslav neighbors, the questions of national identity, attitudes toward communism and contemporary European politics, attitude towards the U.S. and Russia. In global terms, the path to the future emerged in contradiction with the general trends as between 2000 and 2015 democracy was eroding around the world, and the rise of anti-liberal policies and leadership was welcomed both from the right and the left even in Western democracies. "Europe is turning away from power, or to put it a little differently, it is moving beyond power into a selfcontained world of laws and rules and transnational negotiation and cooperation" (Kagan 4). Development of European Union both in terms of enlargement and in terms of strengthening political influence was halted following a major 2004 integration of eastern European and Mediterranean states, and the integration of Romania, Bulgaria and Croatia in 2007 and 2013 respectively. Political regression in Russia and Turkey and their strategic threats are causing worrying processes, new nationalisms and the rise of political religion. Populists and nationalists throughout of the former Yugoslavia ("Western Balkans") are drawing their appeal from popular social or national disappointment and opposition to representative democracy, rule of law, capitalism and economic globalization. In such a context, by no means, a rising antiAmericanism emerges as a fundamental element of resistance to 
European and regional integration, and the inclusion of in the area of the Euro-Atlantic influence. ${ }^{1}$

Anti-Americanism implies rejection of American policies, hostility to American values and way of life, and dislike of the? Americans. ${ }^{2}$ Contemporary anti-Americanism developed under the impressions of the U.S. strategic weaknesses after the period of American unilateralism in international relations (1991-2001). The 9/11 terrorist attack was driven both by Middle Eastern and Western European anti-American groups also linked by political Islam. The leftist intellectual circles in social and political sciences were pointing the alleged frustrations in largely unsuccessful integration and assimilation in Western European societies. After the 9/11 Americans have suffered a "double crisis," one derived from the external anti-Americanism, and the other by internal self-doubt and division (Stam, Shohat xi). The Western liberal-democratic consensus was identified with "neoliberalism" as a derogatory term aimed to delegitimize and condemn the U.S. foreign policy and American capitalism. The economic crisis from 2007-2008 further challenged the U.S. leadership in the Western world and even the concepts of free trade and market economy.

In the most general sense, the contemporary Anti-Americanism is generated by the belief that the U.S., the first and only global superpower, has entered the process of irreversible decadence, that all

\footnotetext{
1 "An antagonism to the United States that is systemic, seeing it as completely and inevitably evil. A view that greatly exaggerates America's shortcomings. The deliberate misrepresentation of the nature or policies of theUnited States for political purposes. A misperception of American society, policies, or goals which falselyportrays them as ridiculous or malevolent" (Rubin IX).

2 "The second dimension of American power that the French (and a number of other Europeans) are uncomfortable with is economic. Globalization and the promotion of the free market have been central to the perceptions about America, at least since the Reagan presidency. The American liberal model with high growth rates, high degrees of inequality combined with low rates of unemployment and low levels of social protection is seen as a major challenge to the continental 'European social model' characterized by the welfare state, high levels of public spending, and high rates of unemployment... After the Reagan-Thatcher challenge to it in the 1980s, came the Clinton-Blair version under the banner of globalization and the 'Third Way' as the only plausible adaptation to its challenges. Meanwhile, the continental welfare state model is in crisis, nowhere more so than in Germany and France, economically the 'sick men of Europe. Thus, in the uneven debate between (French-led) 'territorialists' and (American-led) 'globalists, the post-communist Eastern Europe tended, rather predictably, to support the latter. There is a strong correlation in Western Europe (and France in particular) between critics of marketization/deregulation in the 1990s, not to mention antiglobalization protesters, and the resentment of America's economic power and influence" (Rupnik 102).
} 
the U.S. malevolent and fallacious attributes have been denounced, and that new world leaders have emerged as capable to suppress the further U.S. strategic influence. "Anglophobia" or "Japan-bashing," "Anti-Slavism" and "Sinophobia," although they are powerful concepts, never achieved the importance and influence of the "antiAmericanism." New powers were praised, as Russia, China, Brazil, and India, regardless of dictatorship, corruption, political persecutions and violations of freedom and liberties.

It was commonly irrelevant that the U.S. have never endangered the world peace, especially not as the European did provoking two world wars, or India and Pakistan in 1998. The U.S. also never massively violated basic human principles, as various regimes in Fascism, Nazism and Communism, or the contemporary authoritarian regimes, especially in BRIC and other similar states. The next paradox in global anti-Americanism is in the fact that American society integrates all ethnic and religious communities of mankind. The American social interaction, the assimilation process is voluntary and peaceful. The U.S. still appeal immigrants and migrants from all over the world, sometimes even those from the richest European states, attracted individual and economic freedom.

European anti-Americanism is both left-wing and right-wing phenomenon. Socialists and communists criticize or hate America for its supposed lack of social care, egalitarianism or aggressive, "imperialist" behavior in international relations. The right is demonizing America for its rejection of European conservative, postfeudal, clerical and nationalist collectivism, or for its frivolous mass culture. There is a shared concern that American political and economic individualism, culture and way of life will globally prevail, that American consumerism and cheap massive production will extinguish other economies, and that supranational USA would devour European identities.

The contemporary anti-Americanism is also related to the U.S. retreat from Europe, as the strategic projection that after the fall of communism in Eastern Europe and disintegration of the Soviet Union the American massive strategic involvement no longer needed. ${ }^{3}$

\footnotetext{
3 "Fifty-five percent of the world's development aid and two thirds of all grants-in-aid to the poor and vulnerable nations of the globe come from the European Union. As a share of GNP, U.S. foreign aid is barely one third the European average. If you combine European spending on defense, foreign aid, intelligence gathering, and policing-all of them vital to any sustained war against international crime-it easily matches the current American defense budget. 'Europe' is not inherently weak" (Judt 14).
} 
As America became more interventionist and unilateralist, much of Europe remained committed to multilateralism and more hesitant about any serious military intervention. United States interests have shifted away from Europe toward the Middle East, Central Asia, and China, while Europe has focused primarily on the expanding EU and the broader Mediterranean region. (Nolan 356)

The anti-Americanism is also used as a functional attitude in order to strengthen new European national or supra-national identities. French philosopher Jean-François Revel considers that antiAmericanism represents an almost totalitarian vision, according to which "Americans can do nothing but speak idiocies, make blunders and commit crimes; and they are answerable for all the setbacks, all the injustices and all the sufferings of the rest of humanity" (Golsan 45). Paul Hollander points out that anti-Americanism is encompassing nationalism, anti-Western sentiments, a disdain for capitalism,

the rejection of science, technology, and urban life, fear of nuclear war, general disgust with modernity, the defense of traditional ways of life, and the cultural condescension of established elites; a predisposition to hostility toward the United States and American society, a relentless critical impulse toward American social, economic, and political institutions, and values; it entails an aversion to American culture and its influence abroad, often also contempt for the American national character and dislike of American people, manners, behavior, dress; and a firm belief in the malignity of American influence and presence anywhere in the world. (Stam, Shohat XXI-XXIX)

Economic development and social transformation in the U.S. during the twentieth century have inspired and encouraged similar changes in Western Europe. European social scientists and philosophers have never unanimously valued these changes. However, despite the anti-American propaganda of intellectual elite, the postwar progress and integration of Western Europe have profited on consumerism and the growth of living standards. The new way of life, more "Americanized," was massively accepted. Materialistic hypocrisy is one of the basic arguments of anti-Americanism. Samuel Huntington pointed the criticism of the mismatch between liberal principles and the U.S. foreign policy, as during the Vietnam War. 
After the fall of communism started the fast and successful economic growth of Eastern Europe. During the nineties, it could be anticipated that the global economy will rescue hundreds of millions in Asia from the endemic misery and various forms of enslavement and personal unfreedom. The East European states however have been under strong influence of Soviet propaganda for decades, as well as the leftist circles in Western Europe. The communism criticized the political system and lifestyle in the U.S. Americans were depicted as individuals guided solely by material interests, uninterested in the collectivist values and needs of the community. Russia is an old spiritual nation with a long tradition. Its culture is supposedly superior over Western materialism. At the end of the Cold War, the official communist anti-Americanism was transformed into popular antiAmericanism. In fact, even anti-Americanism was democratized. Obsessions, hatred, prejudices and conspiracy theories, as widespread ingredients of anti-Americanism, have flooded the global internet and even the mainstream media, even in most democratic European states.

During the last decade of the twentieth century, antiAmericanism was still not the dominant topic in politics, diplomacy or social sciences and intellectual reflection. Anti-Americanism massively broke after the 9/11 and the U.S. invasions of Afghanistan and Iraq, supported by the critics of "neoliberalism" or the global warming environmentalist spinning deception when related to the U.S. refusal of the Kyoto protocol. Online, or in public debates, the American postwar support, investments and cultural exchange were gradually forgotten. Even anti-Zionism and anti-Semitism were occasionally included into anti-American discourse.

Increasing anti-Americanism has been documented by dozens of polls in recent years. Zakaria argued that anti-Americanism fills the ideological vacuum left at the end of the Cold War. "Liberal antiAmericanism" emphasizes the hypocrisy of a superpower that employs the rhetoric of idealism and universalism and yet acts unilaterally and in self-interested ways. "Social anti-Americanism" criticizes the U.S. for its overemphasis on free market and individualism and the neglect of social programs. "Sovereign nationalist anti-Americanism" emphasizes U.S. political and military power and its frequent disregard for sovereign nationalism, and specially the U.S. failure to support nationalist movements and its disregard for sovereignty in its military adventures in places like Panama and Iraq. "Radical anti-Americanism" includes both Marxist-Leninist and radical Islamist critiques of the U.S. "Elite anti-Americanism" arises "in countries in which the elite has a long history of looking down on American culture, as is typically true of 
France." "Legacy anti-Americanism" focuses on resentment from the sins committed by the U.S. As in Greece and Mexico, the current antiAmericanism is fueled by the memories of the U.S. military adventures and support in favor of corrupt dictatorships. In China, the most consistently negative views of the U.S. are based on Chinese perceptions of the "century of humiliation," the U.S. support of Taiwan. Chinese attitudes toward U.S. counterterrorism policies are mixed, and images of U.S. material and cultural products are relatively positive (Katzenstein and Keohane 29-36).

"Anti-American sentiments had been latent in Europe and elsewhere before the anti-globalization debate" (Johansson 128), still Anti-Americanism is randomly equaled with anti-globalization. There are also American opponents of globalization, the unfair trade concept which contributes to the U.S. trade deficit and the loss of jobs due to overseas imports from the cheap labor economies. The critique of globalization has become the predominant form of anticapitalism in the post-Communist era. Anti-globalization is also about a positive advocacy for expanded political restrictions on the economy.

The collapse of the Soviet Union and its satellite states supposedly ended the history of the planned, state-ran economy idea and practice. The critiques of globalization and neo-liberalism have filled the empty space left by the previous communist, left-wing critics of capitalism. The critiques of open market and free trade economy mostly ignored the historical failure of the communist enterprise, abandoned even by the communist China.

The critiques of globalization involve the efforts to reassert the primacy of territory over free trade, and of the state over economy, and to strengthen regimes of state ownership and regulation. Antiglobalization advocates the reassertion of the power of the state against the freedom of the market.

The significance of the U.S. both in global politics and global economy fed not only anti-Americanism but also anti-globalization movements as inseparable from hostility to the spread of the global American influence. Jean Baudrillard, a French sociologist, philosopher, cultural theorist and political commentator claimed that the antiglobalization, including terrorism, is the result of globalized modernity. Terrorism is not, he argues, the result of some exterior force that opposes modernization but "the verdict and the sentence that this society directs at itself." With regard to 09/11 there is "a terrorist imagination in all of us [...] Basically, they did it, but we wanted it." 
He saw the perpetrators of September 11 acting out his own dreams and the dreams of others like him. He gave those attacks a sort of universal warrant: "How we have dreamt of this event," he wrote, "how all the world without exception dreamt of this event, for no one can avoid dreaming of the destruction of a power that has become hegemonic. [...] It is they who acted, but we who wanted the deed." Casting caution and false sympathy aside, Baudrillard saw the terrible attacks on the United States as an "object of desire." The terrorists had been able to draw on a "deep complicity," knowing perfectly well that they were acting out the hidden yearnings of others oppressed by the United States' order and power. To him, morality of the U.S. variety is a sham, and the terrorism directed against it is a legitimate response to the inequities of "globalization." (Ajami 57)

Anti-Americanism is also a postcolonial phenomenon, and derives from the belief that the U.S. is the central villain in the contemporary world, regardless of the fact that the U.S. have urged their Western European partners to speed up the process of decolonization. (Indian nuclear arsenal is not the fault of the respective Indian governments but of the "westerners" who invented the weapons as claimed Arundhati Roy). Three important streams flow into ideological anti-Americanism in the former Third World: nationalism, Marxism, and Islamic fundamentalism. Nationalism is the most universal and easily merges with the other two. It encompasses efforts to develop a sense of internal cohesion and unity, to build institutions capable of socializing diverse ethnic and religious groups and impose basic common and shared values. Marxism is the most intellectually consistent of the streams of ideological anti-Americanism, but it derives much of its political force from the critique of imperialism. From the perspective of anti-Americanism, Islamic fundamentalism is also related to the new global anti-Semitism. Even strong strategic U.S. allies, Pakistan, Jordan and Turkey, show deterioration of favorable views of the U.S. after 2006. Public in Albania, Azerbaijan, Bangladesh, Egypt, Iran, Jordan, Morocco, Pakistan and Turkey may approve the American democratic system, but the problem arises with American foreign policies and interventionism, and sometimes even in cases of lack of interventionism. However, around the half of Turks and Moroccans still claim that those who immigrate in the U.S. will gain a better life. After World War II the U.S. gradually pushed off Britain and France as previous major colonial powers in the Middle East, and 
although showed sympathies for local national aspirations and liberating movement, urging the end of colonialism, the overthrowing of the elected government in Iran in 1953 and invasion of Lebanon in 1958 created an initial picture of American anti-communist interventionism. Local attitudes towards the U.S. were also shaped by the support of Israel, becoming especially strong during the sixties.

Anti-Americanism is, however, more than a mere criticism of American world policies a basic, substantial stand on political, economic or value system. Anti-Americanism includes a general rejection of individual liberties, democratic governance and free market capitalism, rejection of democratic ideals and preference for various forms of authoritarianism (Cole 1120). The crisis of the global liberal consensus lasts from about 2001 regardless the China accession into WTO and the significant reduction of world poverty. The worldwide support to authoritarian leaders legitimized violent dictatorships in Russia, China, and Venezuela, and their political clones emerge even within the EU. Russian and Chinese regimes are globally engaged in corruption of politicians, media and academics. The severe economic crisis that started in 2007 launched a debate on the social efficiency of free market economy. The principles of economic freedom were undermined by the U.S. government itself while bailing out the failed banks and hedge funds. And although the U.S. actions in Iraq, Afghanistan and Lybia were actually threatening the consequences of British or European continental colonialism and Soviet interventionism, the U.S. again emerged as solely responsible for the local social disorder internal, religious radicalism, political dictatorship and tribal violence. The demonization of Israel, another form of anti-Americanism, remains a persistent denial of Palestinian terrorism and political thuggery.

The differing threat perceptions in the United States and Europe are not just matters of psychology, however. They are also grounded in a practical reality that is another product of the disparity of power and the structure of the present international order. (Kagan 33)

European Anti-Americanism and wrong shifting or failures of Obama's and current administration have also caused the actual strategic weakness of the EU. The EU leads a vague and hesitant foreign and security policy, especially in relations with those alien powers which endanger the European democratic order, the freedoms and the rule of law as Russia, China and Turkey. The crisis of democracy is obvious 
both within the core (Germany, Italy) and in the later associated states that are more open to the corruption of political system and authoritarian style of political management (Greece, the Visegrád Group etc). Nationalism, clericalism or statism regained their lure. AntiAmericanism as ideological epitome often unites extreme left and right. The EU weakness, populism and corruption opened the path to Russian aggression on Ukraine and strategic pressures on the Baltic and the Balkans, and to the "New Silk Road" Chinese corruption project aimed to endanger the EU economy and democracy with dumped exports and the purchase of political elites.

Between 2000 and 2015 democracy was otherwise eroding around the world. EU integration, transatlantic cooperation, peace and steady economic growth are directly threatened by Russia, Turkey and international Islamic terrorism. Russia is bluffing the war against the terror while cooperating with rogue states as Syria and Iran. Russia still seeks to achieve the nineteenth century strategic intentions in order to compensate its lags in democratic and social achievement. The broader and secured access to the Baltic is to be provided by threats and intimidation. The broader and secured access to the Black sea is to be initially provided by the forceful division of Ukraine and occupation in Crimea. Russia was also backing the unsuccessful attempts of illegal and unconstitutional political changes in Macedonia and Montenegro. Bosnia is divided between Russia and Turkey, and their constituent nations are becoming trivial puppets in the new structure of strategic relations.

Returning to the chosen Montenegro in the context of both global and local, regional anti-Americanism, Montenegro abandoned the post-Soviet paradigm of Yugoslav disintegration adopted by Serbia and the former Yugoslav federal army in 1991, with the expectance of Russian restoration as the great power and major player in international relations. And while in Serbia this strategic vision remained alive, Montengro has decisively assumed a firm position by joining NATO and allying with the U.S. Montenegro has set destination guided by the logic of the developed democratic world instead of the logic of contemporary political regression.

\section{References:}

Chiozza, Giacomo. Americanism and the American World Order. Baltimore: Johns Hopkins University Press, 2009.

Cole, Juan. "Anti-Americanism: It's the Policies". The American Historical Review, Vol. 111, No. 4. (2006): 1120-1129. 
Golsan, Richard. "From French Anti-Americanism and Americanization to the 'American Enemy'? In: The Americanization of Europe. Culture, Diplomacy, and Anti-Americanism after 1945" (edited by Alexander Stephan). New York: Berghahn Books, 2004: 44-68. Johansson, Johny K. In Your Face. How American Marketing Excess Fuels Anti-Americanism. Upper Saddle River, New Jersey: Pearson Education, 2004.

Judt, Tony. "A New Master Narrative? Reflections on Contemporary Anti-Americanism". In: With Us or Against Us. Studies in Global Anti-Americanism. Edited by Tony Judt and Denis Lacorne. New York: Palgrave Macmillan, 2005.

Kagan, Robert. Of Paradise and Power: America and Europe in the New World Order. New York: Alfred A. Knopf, 2003.

Katzenstein, Peter J., and Robert O. Keohane, Anti-Americanisms in World Politics. Ithaca, NY: Cornell University Press, 2007.

Kohut, Andrew, and Bruce Stokes. America Against the World: How We Are Different and Why We Are Disliked. New York: Times Books, 2006.

Nolan, Mary. The Transatlantic Century. Europe and America, 18902010. New York: Cambridge University Press, 2012.

Rubin, Barry, and Judith Colp Rubin. Hating America. A History. New York: Oxford University Press, 2004.

Singh, Robert. Are We All Americans Now? Explaining AntiAmericanisms. In The Rise of

Anti-Americanism, edited by Brendon O'Connor, and Martin Griffiths. London: Routledge, 2006.

Stam, Robert, and Ella Shohat. Flagging Patriotism. Crises of Narcissism and Anti-Americanism. New York: Routledge, 2007.

Rupnik, Jacques. “America's Best Friends in Europe: East-Central European

Perceptions and Policies toward the United States." In: With Us or Against Us. Studies in Global Anti-Americanism. Edited by Tony Judt and Denis Lacorne. New York: Palgrave Macmillan, 2005.

Anti-Americanisms in World Politics (edited by Peter J. Katzenstein and Robert O. Keohane). Ithaca: Cornell University Press, 2007.

Ajami, Fouad. "The Falseness of Anti-Americanism." Foreign Policy, No. 138 (Sep. - Oct., 2003): 52-61 


\section{ODREDIŠTA: EVROPSKI PUTEVI U DEMOKRATIJU I OBMANE ANTIAMERIKANIZMA}

Demokratija podrazumeva slobodu izbora i medija, efikasnu vladu i građansko društvo, pretežno privatno ili korporativno vlasništvo, slobodnu trgovinu i tržišnu ekonomiju, prekograničnu integraciju i saradnju. Nacionalni i socijalni utopizmi obično nastoje da relativizuju, ili ospore neku od gore navedenih demokratskih potpora. Kako moderni demokratski koreni počivaju u Britanskom Komonveltu i protestantskim državama (možda zajedno s Francuskom), buduće odredište liberalnog koncenzusa i dalje je u zavisnosti od uzajamnih veza evropskih demokratskih država i SAD. Ukoliko demokratsko jezgro kao takvo bude propalo, periferije će se sigurno ubrzano obrušavati. Savremeni evropski antiamerikanizam pre svega se odnosi na inherentna evropska pitanja: zajedničko tržište i kapitalizam u EU, NATO i strateška odbrana od autoritarnih ili terorističkih pretnji (Rusija, Kina, Bliski istok i unutrašnji džepovi "multikulturnog“ političkog islama). Antiamerikanizam se zasniva na obmanama ili poluistinama o navodnom političkom, finansijskom i vojnom globalnom imperijalizmu, na etičkoj upitnosti kapitalizma, na korporativnoj pohlepi i dužničkom ropstvu, na američko liderstvo u globalnom zagađenju i klimatskim promenama. Savremeni evropski antiamerikanizam okuplja političke i intelektualne ekstremizme levice i desnice istovremeno, izazivajući koncepte individualne, političke i ekonomske slobode, evropski koncept brisanja granica i razvoja individualnih sloboda. Hibridni rat Rusije protiv Evropske unije uspešno koristi medijsku propagandu i tekuća socijalna i nacionalna nezadovoljstva. Izazivajući zapadni liberalno-demokratski koncenzus, evropski društveni naučnici utrli su ideološke putanje za ruski i kineski prodor u Jugoistočnu i Istočnu Evropu. Budući da se antiamerikanizam u lokalnim odnosima koristi kako bi se osporile evropske i regionalne integracije, obmane antiamerikanizma biće razmatrane pre svega u kontekstu novih budućih odredišta Crne Gore usmerenim prema atlantskim i evropskim institucijama i saradnji.

Ključne reči: antiamerikanizam, Evropska unija, Rusija, Kina, Crna Gora. 